\title{
Knowledge of conjunctivitis among high school students in Pokhara valley of Western Nepal
}

\author{
Sarita Tuladhar*, Jamuna Gurung \\ Department of ophthalmology, Gandaki Medical College \& Teaching Hospital, Pokhara, Nepal
}

\begin{abstract}
Introduction: Conjunctivitis is a common health problem in Nepal. It is inflammation of conjunctiva presenting as red eye. It is a communicable eye disease. Health education to the students and proper management can help spread of the disease. Knowledge of conjunctivitis among school students will help in prevention of the disease. So the study was carried out to assess the knowledge of conjunctivitis among high school students in Pokhara valley of Western Nepal. Materials/ Methods: A school based cross sectional study was performed among six government schools in western Nepal from May 2019 to June 2019. Students from grade eight, nine and ten were included in the study. Data was collected using structured questionnaire including demographic data, knowledge regarding sign symptoms of conjunctivitis, treatment, prevention, complication of conjunctivitis. Data was analysed using SPSS version 11.6. Result: A total of 523 students were included in the study. The mean age of the students was $14.7 \pm 1.2$ years with majority of females (53\%). Nearly $2 / 3^{\text {rd }}$ of the students $(61.6 \%)$ had heard of conjunctivitis. Majority of the students $(87.4 \%)$ of the students mentioned that it is communicable while $80.3 \%$ of the students correctly mentioned its etiology. Majority of the students (97.9\%) mentioned that it is curable with treatment as first option (97.5\%). Majority of the students (98.3\%) correctly responded to the preventive measures but majority of the students (83.2\%) wrongly mentioned mode of transmission. Conclusion: Secondary school students in Western Nepal have poor knowledge of conjunctivitis. Appropriate eye health education should be given to school students to prevent rapid spread of infective conjunctivitis.
\end{abstract}

Keywords: Conjunctivitis, Knowledge, School students

\section{*Corresponding author}

Dr. Sarita Tuladhar

Associate Professor, Department of ophthalmology, Gandaki Medical College \& Teaching Hospital, Pokhara, Nepal

Email: drtuladharsarita@yahoo.com

Received: September 22, 2019

Accepted: June 10, 2020

To cite: Tuladhar S, Gurung J. Knowledge of conjunctivitis among high school students in Pokhara valley of Western Nepal. JGMC Nepal. 2020;13(1):1922. DOI: 10.3126/jgmcn.v13i1.29141 DOI: $10.3126 /$ jgmcn.v13i1.28517

\section{INTRODUCTION}

Conjunctivitis is a common problem worldwide. ${ }^{1}$ Annually estimated 6 million new cases of viral conjunctivitis occur in the United States. ${ }^{2}$ It is inflammation of conjunctiva characterized by hyperemia and edema of the conjunctiva typically associated with discharge. ${ }^{3}$ It can be classified as viral, bacterial, fungal, parasitic, chlamydial, allergic and toxic. Viral conjunctivitis is more common than bacterial ${ }^{2,4}$ and incidence of viral conjunctivitis increases in the summer and rainy season.

Infective conjunctivitis is a common, self-limiting condition. Topical antibiotic may shorten symptoms by one to two days in bacterial infection. Most cases would resolve without treatment within one week. ${ }^{5}$ Viral conjunctivitis resolves in two to three weeks.

Most causes of conjunctivitis are benign, with a self-limited process; however, depending on the immune status of the patient and the aetiology, conjunctivitis can progress to sightthreatening complications like keratitis, uveitis, retinitis, optic neuritis and extra-ocular muscle palsy. ${ }^{6,7}$

The disease spreads through tears, eye discharge, 
contaminated fingers, fomites and aerosols. If one member of family is affected usually whole family members will be infected. Likewise, if one student in class is affected, whole class will be affected. Infected students should refrain from attending school if their behavior is such that they cannot avoid close contact with other students. ${ }^{8}$ Practicing good hygiene is the best way to control the spread of the disease.

Treatment is symptomatic and supportive unless complications occur. Bacterial conjunctivitis usually improves within three to four days of treatment, but viral conjunctivitis takes two weeks to resolve.

Conjunctivitis is a common health problem in Nepal. It is a communicable eye disease. Health education to the students regarding the disease and proper management can help spread of the disease. It is also common in school students. Knowledge develops good habit and good habit stays with person throughout their whole life. No such studies have been performed in our part. So the study was carried out with the objective to assess the knowledge of conjunctivitis among high school students in Pokhara valley of Western Nepal.

\section{MATERIALS AND METHODS}

This is a school based cross sectional study conducted from May 2019 to June 2019. Six government schools were randomly selected among the list of 35 schools of Pokhara. Only government schools were selected because we have recently performed school health programmes with education of common eye problems in some private schools. All students from grade eight, nine and ten were included in the study. All the students present at the time of survey were only included in the study. Absentees were excluded from the study.

Sample size calculation- Using the formula for cross sectional studies and assuming a prevalence of $50 \%$ (since no previous study has been carried out on the subject matter in our part of world), a sample size of 384 was calculated by using the formula, $n=z^{2} p(1-p) / d^{2}$, where $\mathrm{z}=1.96, \mathrm{p}=0.5$ and $\mathrm{d}=5 \%$. However, this was exceeded, and 523 students were recruited into the study.

The dependent variable was knowledge and independent variables were age and gender, class grade of the student. Data was collected using structured questionnaire. The questionnaire was prepared after reviewing articles and standard books. The questionnaire included (i) demographic data, (ii) having heard of conjunctivitis, (iii) cause of conjunctivitis, (iv) disease communicable or not, (v) symptoms of conjunctivitis, (vi) disease curable or not, (vii) treatment modalities, (viii) preventive measures, (ix) necessity of treatment, (x) complication of conjunctivitis, (xi) mode of transmission.

The students were asked to fill the questionnaire completely. They were informed only to fill only one best option in the question. Questions (ii), (iii), (iv), (v), (vi), (ix), (x), (xi) reflected knowledge of conjunctivitis while questions (vii) and (viii) reflected students practice in conjunctivitis. The data was collected by ophthalmologist visiting the schools. The data was analysed using SPSS version 11.6. Mean and standard deviation were calculated. All the result was expressed in frequency and percentage. Ethical approval was taken from ethical review committee (IRC) of Gandaki Medical College (GMC).We had also taken permission from educational office and school personnel. Verbal assent was taken from the participants.

\section{RESULT}

A total of 523 students were included in the study. The minimum age of the students was 10 years and maximum was 15 years with the mean age of $14.7 \pm 1.2$ years. In our study, $47 \%$ (246) of the students were males while $53.1 \%$ (277) were females. Details of the students age and sex distribution is shown in table 1.

Table1: Age and sex distribution of the students

\begin{tabular}{llll}
\hline Sex & \multicolumn{1}{|c|}{$\begin{array}{c}\text { Age (10-15 yrs } \\
\text { n (\%) }\end{array}$} & $\begin{array}{c}\text { Age ( > 15 yrs) } \\
\text { n (\%) }\end{array}$ & Total n (\%) \\
Male & $183(35 \%)$ & $63(12 \%)$ & $246(47 \%)$ \\
Female & $200(38 \%)$ & $77(15 \%)$ & $277(53 \%)$ \\
\hline
\end{tabular}

Out of 523 students, nearly $2 / 3^{\text {rd }}$ of our students $(61.6 \%)$ mentioned that they had heard of conjunctivitis while $38.4 \%$ had not heard of conjunctivitis.

In our study, $87.4 \%(457 / 523)$ of the students mentioned that conjunctivitis is communicable while $12.6 \%(66 / 523)$ mentioned it as non communicable.

Most of the students $80.3 \% \quad(420 / 523)$ mentioned organism as the cause of conjunctivitis followed by hot climate $13.8 \%$ ( 72/523) and water 3.8\% (20/523). Details of students knowledge regarding cause of conjunctivitis is shown in table 2 .

Table 2: Cause of conjunctivitis

\begin{tabular}{lll}
\hline Cause of conjunctivitis & Number & Percentage \\
Organism & 420 & 80.3 \\
Ghost & 10 & 1.9 \\
Water & 20 & 3.8 \\
Hot climate & 72 & 13.8 \\
Don't know & 1 & 0.2 \\
Total & 523 & 100 \\
\hline
\end{tabular}

Majority of the students correctly mentioned the symptoms of the conjunctivitis. Details are shown in table 3. 
Table 3: Symptoms of conjunctivitis

\begin{tabular}{lcc}
\hline Symptoms & Numbers & Percentage \\
Redness & 89 & 17 \\
Discharge & 15 & 2.9 \\
Itching & 47 & 9 \\
All of the above & 363 & 69.4 \\
Others & 9 & 1.7 \\
Total & 523 & 100 \\
\hline
\end{tabular}

Majority of the students $97.9 \%(512 / 523)$ responded that the conjunctivitis was curable. Regarding health seeking behavior of the students, $97.5 \%$ (510/523) of the students mentioned that one should go to the hospital. Details are shown in table 4.

Table 4: Health seeking behavior of the students

\begin{tabular}{lll}
\hline Health seeking behaviour of students & Number & Percentage \\
Go to hospital & 510 & 97.5 \\
Put gazal & 2 & 0.4 \\
Put milk & 8 & 1.5 \\
Go to traditional healers & 3 & 0.6 \\
Total & 523 & 100 \\
\hline
\end{tabular}

For prevention of conjunctivitis, $98.3 \%$ of the students mentioned that one should go to the hospital or clean eyes with cold water. Details are shown in table5.

Table 5: Knowledge regarding prevention of conjunctivitis

\begin{tabular}{lcc}
\hline Prevention of conjunctivitis & Frequency & Percentage \\
Clean eyes with water & 92 & 17.6 \\
Go to hospital & 66 & 12.6 \\
Both of the above & 356 & 68.1 \\
Others & 9 & 1.7 \\
Tota1 & 523 & 100 \\
\hline
\end{tabular}

Majority of the students 98.5\%(515/523) mentioned complications of conjunctivitis correctly. Only $1.5 \%$ said there will be no complication of conjunctivitis. Details are shown in table 6.

Table 6: Knowledge regarding complication of conjunctivitis

\begin{tabular}{lcc}
\hline Complications & Frequency & Percentage \\
Visual acuity decreases & 107 & 20.5 \\
Other ocular diseases occurs & 33 & 6.3 \\
Both of the above & 375 & 71.7 \\
Nothing happens & 8 & 1.5 \\
Total & 523 & 100 \\
\hline
\end{tabular}

Majority of the students wrongly replied the mode of transmission of conjunctivitis as they mentioned it is transmitted by viewing eyes of patients with conjunctivitis (83.2\%). Details are shown in table 7 . This showed the necessity of health education to the high schools students as conjunctivitis is a communicable disease which has become endemic.
Table7: Mode of spread of conjunctivitis

\begin{tabular}{lcc}
\hline Mode of transmission of conjunctivitis & Frequency & Percentage \\
Tears & 29 & 5.5 \\
Blood & 25 & 4.8 \\
Discharge & 34 & 6.5 \\
By viewing eyes of patients with conjunctivitis & 435 & 83.2 \\
Total & 523 & 100 \\
\hline
\end{tabular}

\section{DISCUSSION:}

Conjunctivitis is a communicable disease. It occurs throughout the year but more cases are seen in summer and rainy season in our country. Infective conjunctivitis is highly contagious and can easily spread in schools and at home. An outbreak of any communicable disease can be prevented by eliminating or reducing the source of infection, interrupting the transmission and protecting the person at risk.

In Nepal, majority of our community is literate. High school students are the future of our country and they are given basic knowledge of different common communicable diseases. Conjunctivitis is such a disease which can be controlled if properly treated and proper hygiene and habits practiced. So, if high school students have proper knowledge regarding the disease, they will tell their parents about the disease which help to change the knowledge and attitude regarding the disease.

No studies have been done in Nepal, regarding knowledge of conjunctivitis though similar studies have been done abroad., 10 In our study though majority of the students correctly responded saying they have heard of conjunctivitis, only $80.3 \%$ of them reported that organism is the cause. In a similar study done in Africa ${ }^{10}, 81 \%$ of the students said that they have heard of conjunctivitis.

In our study, $69.4 \%$ of the students mentioned redness, discharge and itching as the symptoms of the study. But other studies that have been done by Bhat et $\mathrm{al}^{9}$ and Prabhu et $\mathrm{al}^{11}$ showed redness as the most common symptom. Likewise, study by Everitt et $\mathrm{al}^{12}$ showed redness as the most common symptom. Majority of the students said that conjunctivitis was curable and they have to go to hospital in case of conjunctivitis. But some said that they put gazal or milk or go to traditional healer. This reflects our community's belief towards conjunctivitis. Other studies also showed people putting different things like onion, breast milk, sugar water, urine etc as traditional treatment methods. ${ }^{10,13,14}$

In our society there is myth that conjunctivitis is transmitted by viewing eyes of patients with conjunctivitis. Our study showed its reflection as majority of the students mentioned same cause. Health education together with 
written materials, such as pamphlets, is safe and costeffective with high rates of patient satisfaction and compliance. ${ }^{15}$ So, if students are provided proper health education, it will help to change their attitude and practice towards the disease. This will help to reduce the burden of the disease and possible complications.

\section{CONCLUSION}

In Nepal, majority of our community is literate. High school students are the future of our country and they are given basic knowledge of different common communicable diseases. Secondary school students in Western Nepal have poor knowledge of conjunctivitis. Appropriate eye health education should be given to school students to prevent rapid spread of infective conjunctivitis. Also early presentation to eye care centers for its treatment should be encouraged.

\section{REFERENCES}

1. Adebayo A, Parikh JG, McCormick SA, Shah MK, Huerto $\mathrm{RS}, \mathrm{Yu} \mathrm{G}$, et al. Shifting trends in in vitro antibiotic susceptibilities for common bacterial conjunctival isolates in the last decade at the New York Eye and Ear Infirmary. Graefes ArchClin Exp Ophthalmol. 2011;249(1):111-9.

2. AzariAA, Barney NP.Conjunctivitis Asystematic review of diagnosisand treatment.JAMA.2013;310(16):172130.DOI:10.1001/jama.2013.280318

3. Kumar R, Dabas P, Mehra M, Ingle GK, Saha R, Kamlesh R. Ocular morbidity amongst primary school children in Delhi. Health Popul Perspect Issues. 2007;30:2229.

4. American Academy of Ophthalmology Cornea/ External Disease Preferred Practice Pattern Panel. Conjunctivitis Preferred Practice Pattern. San Francisco, CA: American Academy of Ophthalmology; 2018.

5. Sheikh A, Hurwitz B. Topical antibiotics for acute bacterial conjunctivitis: a systematic review. Br J Gen Pract. 2001;51:473-7

6. Pihos AM. Epidemic keratoconjunctivitis: a review of current concepts in management. J Optom. 2013;6(2):69-74. DOI: 10.1016/j.optom.2012.08.003

7. Shaikh S, Ta C. Evaluation and management of Herpes Zoster Ophthalmicus. Am Fam Physician. 2002;66(9):1723-30.

8. Crounau H, Kankanala RR, Mauger T. Diagnosis and management of red eye in primary care. Am Fam Physician. 2010;81:137-44.PMID: 20082509.
9. Bhat N, Patel R, Reddy JJ, Singh S, Sharma A, Multani S. Knowledge and Awareness of Eye Flu among the Dentists and Dental Auxiliaries of Udaipur City, Rajasthan. Int J Prev Med. 2014 Jul;5(7):920-3.

10. Bodunde OT, Sholeye 00, Onabolu 00, Otulana TO, Ajibode HA. Perception of red eye among senior secondary students in Sagamu, Southwest Nigeria. J Family Med Prim Care. 2016;5:89-93.

11. Prabhu P B, Muraleedharan A, Afsana EK, KV Raju. Attitude and practices of subjects with recent history of conjunctivitis, regarding treatment and prevention of the disease. BMH Medical Journal. 2015;2(4):91-6.

12. Everitt H, Little P. How do GPs diagnose and manage acute infective conjunctivitis? A GP survey. Fam Pract. 2002;19:65860.

13. Ayanniyi AA, Olatunji FO, Mahmoud AO, Ayanniyi RO. Knowledge and attitude of guardians towards eye health of primary school pupils in Ilorin, Nigeria. Niger Postgrad Med.J. 2010;17:1-5.

14. Omolase CO, Fadamiro CO, Omolase BO, Adido J, Adepoju FG. Barriers to uptake of orthodox eye care in a rural Nigerian community. Trop J Health Sci. 2007;14:23-5.

15. Visscher KL, Cindy ML, Thomas HM. Evidence-based treatment of acute infective conjunctivitis. Can Fam Phys. 2009;55:1071-5. 